\section{The European Electricity Market: The Dual Challenge of Liberalisation and Climate Protection}

\author{
Opportunities for the German \\ energy industry
}

The European electricity market is currently facing two major challenges: open competition and climate protection. Since the introduction of the 1997 European Commission Directive, the gradual liberalisation of the European electricity sector has intensified competition between electricity suppliers. The aim of the 2003 European Council Directive on emissions trading, on the other hand, is to reduce carbon dioxide emissions. Moreover, in its 1997 White Paper the European Commission recommends increasing the share of renewable energy used for electricity generation to $12 \%$ by 2010 .

Over the next 10 to 20 years, numerous conventional power plants will be closing down in Germany on the grounds of old age, and so now the question emerges as to how security of electricity supply can be achieved cost efficiently but still be environmentally friendly or climate friendly. As a consequence, electricity suppliers who can produce electricity cheaply, but at the same time in an environmentally or climate-friendly manner, benefit by a comparative advantage. In view of this situation, German power plant operators are about to be offered a unique opportunity to gain a long-term competitive edge on international electricity markets through early investment in pioneering technologies.

\section{The liberalisation of the European electricity market}

The liberalisation of the electricity market, which entails guaranteed competition, fewer external - especially political - interventions and regulatory measures, and open market access for new suppliers, is a global phenomenon. Although the reasons for market opening may vary substantially from country to country, one of the primary goals - apart from security of supply - is often the possibility of offering customers lower prices than they would pay on the monopolistic electricity market.

Although only a few countries in the world have fully liberalised their electricity markets to date, most countries are actually aiming for full market opening in the near future. In Europe, for example, the European Commission Directives of 1997 (Directive 96/92/EC) ${ }^{1}$ and 2003 (Directive 2003/54/EC) ${ }^{2}$ stipulate gradual liberalisation of the electricity markets of all European Union countries. Under the terms of the 1997 Directive, an average $25 \%$ share of the electricity markets was to be opened up in each EU country by as early as 1999 . Now full market liberalisation is sought by July 2007.

However, the implementation of this Directive actually varies substantially across the countries in Europe (cf. table 1). Germany liberalised its electricity market fully in 1999, for example, following the forerunners Norway, Sweden and Great Britain. Austria and Denmark have almost entirely liberalised their markets since, while Spain hopes to achieve full market opening soon. France and Italy, by contrast, have not yet decided when they plan to open their electricity markets to external competition. Given that only a few electricity suppliers are operating in these two countries, these electricity markets are still dominated by a monopoly (France) and an oligopoly (Italy).

\section{Different levels of market opening distort competition}

The different degrees of market opening and liberalisation in the European electricity market are causing competitive distortions. Some electricity suppliers are already dealing with fully competitive conditions, while others are still operating from a monopolistic position. The opening up of the market has placed electricity suppliers in a new situation entailing more intense competition, which is leading to an adjustment of supplier behaviour. As the liberalisation of the electricity market was carried out extremely rapidly in Germany, the process of change was highly dynamic in this case. Some electricity suppliers merged with others so as to be able to stand up to the growing competition.

In order to be able to supply electricity as cheaply as possible, power plant operators must use economies of scale. ${ }^{3}$ The larger and the more varied the mix of power

\footnotetext{
${ }^{1}$ Directive 96/92/EC of the European Parliament and of the Council of 19 December 1996 concerning common rules for the internal market in electricity.

2 Directive 2003/54/EC of the European Parliament and of the Council of 26 June 2003 concerning common rules for the internal market in electricity and repealing Directive 96/92/EC.

${ }^{3}$ Economies of scale is the term used to describe the cost savings that enterprises can achieve through large-scale production. High output and sales volumes can be the basis for cost leadership, which makes it more difficult for new competitors to enter the market. The result is a further increase in the market shares of leading enterprises.
} 
Table 1

Liberalisation of European Electricity Markets

\begin{tabular}{|c|c|c|c|c|c|}
\hline Country & $\begin{array}{c}\text { Degree of } \\
\text { liberalisation } \\
(\%)\end{array}$ & $\begin{array}{l}\text { Date of complete } \\
\text { liberalisation }\end{array}$ & Main suppliers & $\begin{array}{l}\text { Market share } \\
\qquad(\%)\end{array}$ & $\begin{array}{c}\text { Consumers who } \\
\text { have changed } \\
\text { supplier (\%) }\end{array}$ \\
\hline Austria & 100 & 2003 & EVN, Verbund, Wiener Stadtwerke & 68 & 5 to 10 \\
\hline Belgium & 35 & 2007 & Electrabel & 97 & 5 to 10 \\
\hline Denmark & 90 & 2003 & SK Power Company & 75 & Data unavailable \\
\hline Finland & 100 & 1997 & Fortrum, Ivo Group & 54 & 30 \\
\hline France & 30 & Considerations in progress & EDF & 98 & 5 to 10 \\
\hline Germany & 100 & 1999 & E.On, EnBW, RWE, Vattenfall & 63 & 10 to 20 \\
\hline Greece & 30 & Not considered & AEH (public enterprise) & 100 & None \\
\hline Ireland & 97 & 2007 & ESB & 97 & 30 \\
\hline Italy & 35 & Not considered & Elettrogen, Enel & 79 & Less than 5 \\
\hline Luxembourg & 50 & 2007 & Cegetel & 90 & Data unavailable \\
\hline Netherlands & 33 & 2003 & Essent, Nea & 64 & 10 to 20 \\
\hline Portugal & 30 & Not considered & EDP & 85 & Less than 5 \\
\hline Spain & 45 & 2003 & $\begin{array}{l}\text { Endesa, Hidroelectrica del Cantabrico, } \\
\text { Iberdrola, Union Fenosa }\end{array}$ & 79 & Less than 5 \\
\hline Sweden & 100 & 1998 & Sydkraft, Vattenfall & 77 & Data unavailable \\
\hline United Kingdom & 100 & 1998 & $\begin{array}{l}\text { British Energy, Innogy, Powergen,Scottish } \\
\text { and Southern Energy, Scottish Power }\end{array}$ & 44 & 80 \\
\hline
\end{tabular}

Source: European Commission: Benchmark Report, Brussels 2003.

plants available, the more favourable are the possibilities for economic optimisation in the electricity sector. However, one of the consequences of enterprise mergers is expanding market shares for individual electricity suppliers. This causes decreased instead of increased competition. After all, an increase in market shares can lead once again to a more oligopolistic market structure (with only a few electricity suppliers), and this would result not in falling, but more probably in rising prices for electricity.

However, whether an electricity supplier can actually implement strategies in the sector that influence the electricity market depends, in particular, on the prevailing market conditions. For example, the conditions of access to the various levels of the electricity market (production, sales and distribution) can be decisive. The construction of a new power plant entails enormous investment costs. The long time delay prior to starting production while the plant is being constructed implies that the entry barrier to the production segment of the market is much higher than the obstacles that can be expected to hamper entry into electricity sales.

Electricity trading may create additional market distortions if the transport of electricity in Europe is not made subject to a uniform pricing system. In Germany, for example, an agreement between the associations operating in the energy sector (Verbändevereinbarung) regulates prices for electricity trading and transport. In the future, an independent regulatory authority will supervise trading and guarantee uniform and non-discriminatory pricing.

\section{European climate policy: emissions trading and promotion of renewable energy sources}

The European Union's climate protection policy is currently based on two main pillars: first, trading in emissions permits, to reduce $\mathrm{CO}_{2}$ emissions, ${ }^{4}$ and second, the EU directive on the promotion of electricity produced from renewable energy sources. Emissions trading in the EU will initially be restricted to the energy sector and to some branches of industry, and to just one greenhouse gas $-\mathrm{CO}_{2}{ }^{5}$ The initial allocation of emissions permits will be laid down in a National Allocation Plan

\footnotetext{
${ }^{4}$ Directive 2003/87/EC of the European Parliament and of the Council of 13 October 2003 establishing a scheme for greenhouse gas emission permits trading within the Community and amending Council Directive $96 / 61 / \mathrm{EC}$.

5 By contrast, the international commitments on emission reductions refer to six different greenhouse gases.
} 
(NAP) for each country. On 28 May 2004, the German Bundestag passed the Greenhouse Gas Emissions Trading Act (Treibhausgas-Emissionshandelsgesetz), and a draft law on the National Allocation Plan for greenhouse gas emissions permits in the trading period 2005 to 2007 (Zuteilungsgesetz).

Under the EU burden-sharing agreement, Germany has committed itself to reducing greenhouse gas emissions that damage the climate by a total of $21 \%$ (relative to 1990) by the period 2008 to 2012 . The NAP stipulates a $\mathrm{CO}_{2}$ budget for Germany of an annual 859 million tonnes from 2005 to 2007 and 844 million tonnes from 2008 to $2012 .{ }^{6}$ In the first trading period, 503 million tonnes per annum are allocated to the energy and industrial sectors, while 495 million tonnes per annum are allocated to these sectors in the second trading period. On recent figures, this corresponded in these two sectors to a total emissions reduction of only 10 million tonnes, or $2 \%$ relative to average emissions in the period 2000 to 2002.

\section{German National Allocation Plan designates emissions permits}

In principle, emissions trading is a cost-efficient approach to emissions reduction because each emitter can choose, depending on the abatement costs, whether to purchase emissions permits or to reduce emissions (and possibly sell off surplus permits). Nonetheless, the German energy industry is concerned that it will suffer substantial competitive disadvantages. Given the special allocation regulations laid down in the NAP, they actually have little cause for worry. Emissions permits are granted free of charge both to existing plants and to new installations. In the case of old plants, the allocation is essentially determined on the basis of the installation's emissions in the period 2000 to 2002 , while in the case of new installations it depends on a predetermined technical standard.

Newly built power plants are granted emissions permits for a maximum $750 \mathrm{~g}$ of $\mathrm{CO}_{2} / \mathrm{kWh},{ }^{7}$ which corresponds to the volume of emissions released by state-ofthe-art coal-fired power stations. These installations can be operated for 14 years following the date of commis-

6 Federal Ministry for the Environment, Nature Conservation and Nuclear Safety: 'National Allocation Plan for the Federal Republic of Germany, 2005-2007'. Berlin, 31 March 2004, http://www.bmu.de/files/ nap_kabi_en.pdf.

7 Like existing plants, new installations are subject to 'benchmarks', which are derived on the basis of the best available technology. The aim of this approach is to ensure consistency in the allocation of permits to comparable products - as measured in emission factors per unit of output (kWh or tonne) sioning without being subject to any requirement to reduce emissions. In addition, a reserve of 3 million tonnes will be set aside for new entrants to the market. Power plant operators who replace an old plant with a new installation can transfer the permits allocated to the old plant to the new installation for a total of four years, even if the new installation is more efficient and does not require an emissions permit of the same dimension. The new installation can then be operated for another 14 years without any obligation to reduce emissions. The so-called deduction rule stipulates that plants that are older than 30 years and whose net efficiency does not exceed $31 \%$ for lignite and $36 \%$ for coal are required to reduce emissions by an additional $15 \%$.

The efforts to date on the part of power plant operators to reduce emissions by modernising old plants or improving the efficiency of new plants have been recognised to an extent by the 'early action' rule. Plants that first commenced operations between 1994 and 2002 are exempted from mandatory reductions for a period of 12 years. Power plants that were modernised during this period and whose emissions were reduced by at least $7 \%$ on completion of modernisation in 1994 and by a maximum of $15 \%$ on completion of modernisation in $2002^{8}$ have also been exempted from mandatory reduction commitments for 12 years. The operators of nuclear power plants due for decommissioning by 2007 will be credited with an annual emissions permit of 1.5 million tonnes of $\mathrm{CO}_{2}$. In addition, a dual benchmark with separate emission limits for power output and heat output has been introduced in order to avoid discrimination against combined heat and power plants.

\section{A quarter of European greenhouse gas emissions originate in Germany}

Germany is responsible for almost a quarter of Europe's greenhouse gas emissions, which makes it the largest emitter of greenhouse gas in the EU. The generous allocation of emissions permits in Germany has already reduced the price of emissions permits on the European futures market by 2 euro to 8 euro per tonne of $\mathrm{CO}_{2}{ }^{9}$ However, it remains doubtful whether the allocation of emissions permits in Germany and the special regulations that have been negotiated will suffice to send out the signals required to bring about a transition to envi-

\footnotetext{
${ }^{8}$ Reduction of $8 \%$ on completion of modernisation in 1995 , of $9 \%$ on completion of modernisation in 1996, etc., up until 2002. If emissions have been reduced above and beyond this minimum value, these are also exempt from mandatory commitments.

9 DowJones VWD News, TradeNews Emissions, no. 1. Frankfurt/ Main, 16 July 2004.
} 
ronmentally friendly electricity production. ${ }^{10}$ If longterm sustainable reduction of greenhouse gas emissions is to be achieved (and the current goal is an $80 \%$ reduction on 1990 by the middle of the century), then the emissions trading system must unquestionably define much stricter reduction targets.

\section{Promotion of renewable energy}

In order to promote the use of renewable energy in electricity production, in its 1997 White Paper entitled 'Energy for the Future: Renewable Sources of Energy' 11 the European Union stipulated doubling the share of renewable energy sources used in total energy consumption to $12 \%$ by 2010 . Moreover, in the future electricity will be subject to mandatory labelling, so that buyers can identify the energy source used in its production. ${ }^{12}$ A directive passed in 2001 specifically promotes the production of electricity from renewable energy sources. ${ }^{13}$ The individual EU countries have in turn defined concrete targets for the share of renewable energy sources to be used to cover electricity needs up to 2010 .

The measures the different European countries are adopting in pursuit of these targets vary substantially. Some countries, for example Belgium, Spain, France and Portugal, demand concrete feed-in tariffs (similar to the German system) to compensate for the higher cost of producing electricity from renewable energy sources. Others, for instance Finland, the Netherlands and Sweden, have offered tax concessions to increase the incentive to build more of these installations. Austria, Italy and Great Britain have all introduced a quota model that prescribes the share of renewable energy sources to be used in electricity production. ${ }^{14}$ Operators producing

\footnotetext{
10 The European Commission has criticised Germany's special regulations, especially the rule on transferring permits from old plants to new installations and the ex ante allocation of emissions permits.

11 Commission of the European Communities: 'Energy for the Future: Renewable Sources of Energy'. White Paper for A Community Strategy and Action Plan. Brussels 1997.

12 Directive 2003/54/EC of the European Parliament and of the Council of 26 June 2003 concerning common rules for the internal market in electricity and repealing Directive 96/92/EC.

${ }^{13}$ Commission of the European Communities: Amended Proposal for a Directive of the European Parliament and of the Council on the promotion of electricity produced from renewable energy sources in the internal electricity market. Brussels 2000; Directive 2001/77/EC of the European Parliament and of the Council of 27 September 2001 on the promotion of electricity produced from renewable energy sources in the internal electricity market. Official Journal of the European Communities L 283/33 of 27 October 2001.

14 The quota model entails the requirement that a specific share of electricity generation must be based on renewable energy sources. If an enterprise is unable to fully meet this requirement, it can, for example, purchase additional shares.
}

Figure 1

\section{Target Agreements on Share of Renewable Energy Used for Electricity Generation in the EU by 2020}

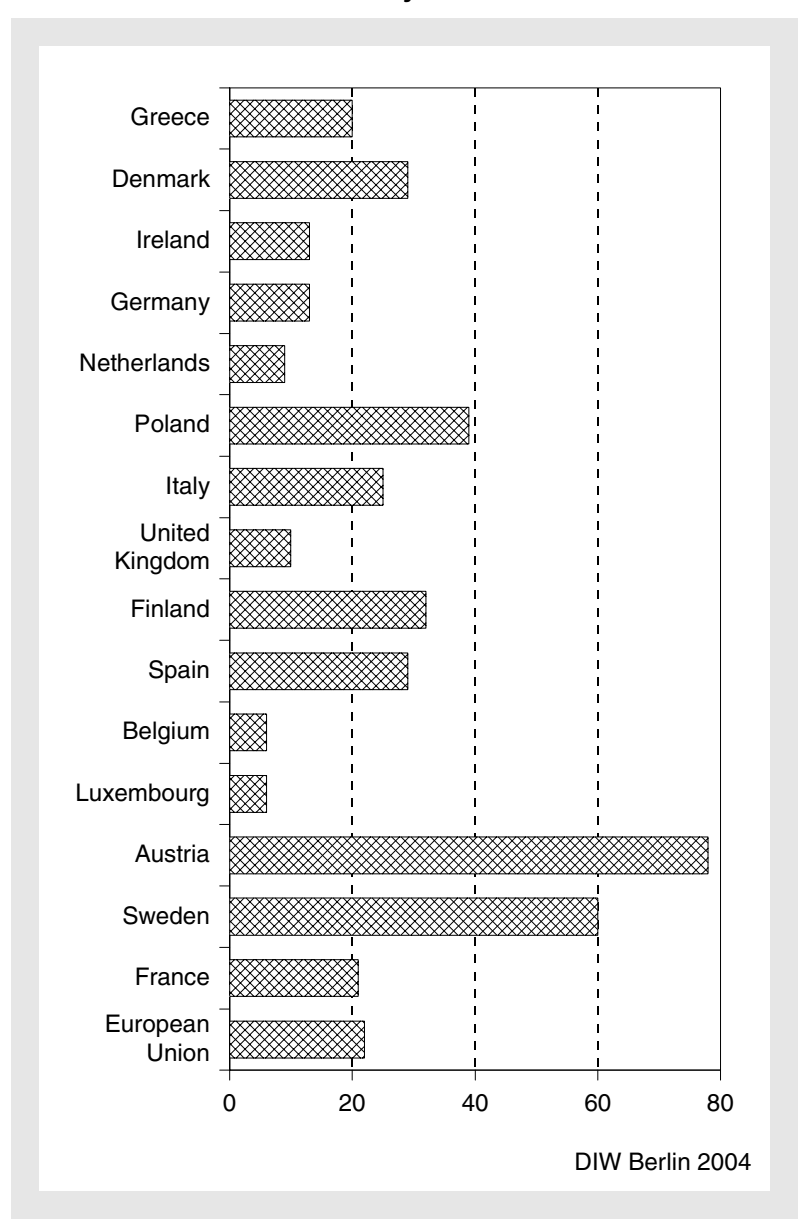

Source: European Commission 2001.

electricity from renewable energy sources are issued with certificates or licences, and these can be traded between electricity suppliers, not unlike the emissions trading system. In Germany, the law of July 2004 providing for the precedence of renewable energy sources specifies a target of doubling today's share of renewable energy sources to $12.5 \%$ by 2010 and increasing it further to at least $20 \%$ by $2020 .{ }^{15}$ The long-term intention is to increase the share of primary energy consumption based on renewable energy sources to $50 \%$ by 2050 (cf. figure 1).

\footnotetext{
15 Precedence of Renewable Energy Sources Act (Erneuerbare-Energien-Gesetz, EEG) of the Federal Republic of Germany of 29 March 2000.
} 
Table 2

Gross Electricity Generation in Germany by Energy Source

In terawatt hours (TWh)

\begin{tabular}{|lrr|r|r|r|r|r|}
\hline & \multicolumn{1}{|c|}{1996} & 1997 & \multicolumn{1}{c|}{1998} & 1999 & 2000 & 2001 & 2002 \\
\hline Hard coal & 152.7 & 143.1 & 153.4 & 143.1 & 143.1 & 138.4 & 135.0 \\
Lignite & 144.3 & 141.7 & 139.4 & 136.0 & 148.3 & 154.8 & 159.0 \\
Mineral oil & 8.1 & 7.4 & 6.7 & 6.3 & 5.2 & 6.1 & 6.0 \\
Natural gas & 45.6 & 48.1 & 50.8 & 51.8 & 49.2 & 55.5 & 54.0 \\
Other combustible fuels & 15.6 & 16.7 & 18.4 & 18.9 & 20.8 & 19.7 & 19.4 \\
Nuclear power & 161.6 & 170.3 & 161.6 & 170.0 & 169.6 & 171.2 & 164.8 \\
Wind energy & 2.0 & 3.0 & 4.5 & 5.5 & 9.5 & 10.5 & 16.8 \\
Hydro energy & 22.7 & 22.0 & 22.5 & 27.4 & 27.7 & 25.6 & 26.0 \\
Total & 552.6 & 552.3 & 557.3 & 559.0 & 573.4 & 581.8 & 581.0 \\
\hline
\end{tabular}

Source: Working group on Energy Balances.

\section{Sustainable electricity generation in Germany}

Numerous conventional power stations will be shut down over the next 10 to 20 years in Germany on the grounds of old age. ${ }^{16}$ The agreed phasing out of nuclear energy has created the need for extensive additional modernisation of existing power plants and construction of many new installations. The decisions to be faced in the near future regarding investment in new power plant technologies will depend fundamentally, however, on developments on the liberalised European electricity market and on climate policy. Essentially, if emissions trading leads to an extremely high price for emissions permits, then power plants with high emission levels will rapidly become economically inefficient.

The $\mathrm{CO}_{2}$ emissions released by individual power plants depend essentially on the fuel source and the efficiency of the plant in converting energy. Electricity production has risen slightly in Germany since the beginning of the 1990s. Nonetheless, the volume of $\mathrm{CO}_{2}$ emissions released during electricity generation decreased by almost 8\% between 1991 and 2002, while specific $\mathrm{CO}_{2}$ emissions (emissions per kilowatt hour of electricity generated) actually fell by approximately $14 \%$ over the same period. ${ }^{17}$ The decrease was first and foremost a

\footnotetext{
${ }^{16}$ Also cf.: Hans-Joachim Ziesing and Felix Christian Matthes: 'Energiepolitik und Energiewirtschaft vor großen Herausforderungen'. In: Wochenbericht des DIW Berlin, no. 48/2003.
}

consequence of the replacement of conventional coalfired stations by gas-fired stations, nuclear power plants and wind turbines. In addition, the power plant mix in eastern Germany was overhauled.

Electricity production in Germany is currently based primarily on nuclear energy, hard coal and lignite (cf. table 2). Of these, lignite combustion generates the highest $\mathrm{CO}_{2}$ emissions. As Germany still depends to a substantial extent on coal and lignite for electricity generation, it is one of the major emitters of $\mathrm{CO}_{2}$ in Europe (cf. figure 2).

Modern gas-fired and steam-driven power plants, which currently account for only around $9 \%$ of electricity production in Germany, result in much lower emissions of climate-damaging greenhouse gases. Electricity generation in combined heat and power plants has a high total utilisation rate for the fuel used because the waste heat released during electricity generation is made available for heating purposes. Electricity generation using nuclear energy, by contrast, does not result directly in any greenhouse gases that causes climate damages, but this method harbours numerous other environmental risks during production and final disposal.

\footnotetext{
${ }^{17} \mathrm{CO}_{2}$ emissions from electricity production have increased again perceptibly since 1999, however; in 2002 they were $6.2 \%$ higher than in 1999, while electricity production increased by $4.5 \%$ over the same period. Thus, specific $\mathrm{CO}_{2}$ emissions have actually increased again somewhat in this sector in recent years.
} 


\section{Figure 2}

\section{$\mathrm{CO}_{2}$ Equivalent per Kilowatt Hour of Electricity Generated in EU Countries \\ In grams}

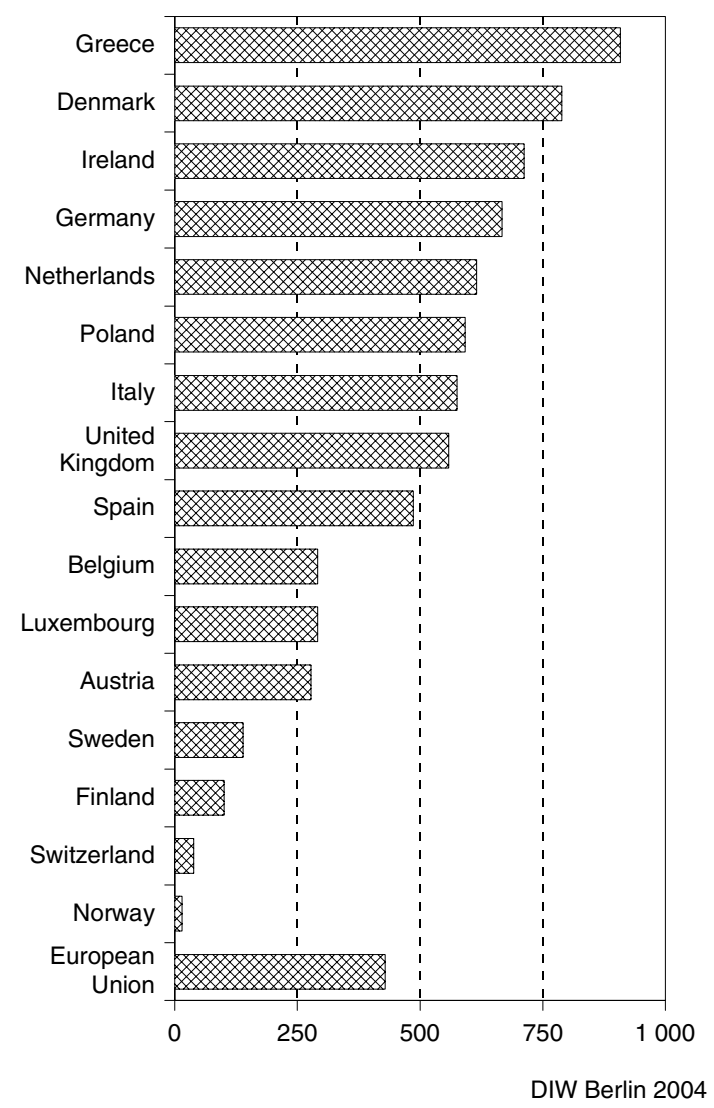

Source: European Commission 2001

\section{Early investment in pioneering technologies to secure a competitive advantage}

The future of energy production depends crucially on current demographic, social, techno-economic and political conditions, and on how these are expected to develop. The 14th German Bundestag Enquête Commission on Sustainable Energy Supplies in View of Globalisation and Liberalisation expects that German electricity demand will amount to around 570 terawatt hours (TWh) in 2020. Total power plant capacity would thus have to increase from around 115 gigawatts $(\mathrm{GW})$ in 1998 to up to $120 \mathrm{GW}$ in 2020 , and around $128 \mathrm{GW}$ in $2050 .^{18}$ Additional power plant capacity of around $40 \mathrm{GW}$ will be required by $2020 .{ }^{19}$ Figure 3 shows the power capacity predicted under various scenarios. ${ }^{20}$ Jülich Research Centre's status quo scenario actually predicts a more significant decline in power plant capac- ities. Under this scenario, additional plant capacity of up to $80 \mathrm{GW}$ will be required in 2020 .

The sustainability scenario described by the Federal Environmental Agency in Germany (Umweltbundesamt, $U B A$ ) implies that by $2020, \mathrm{CO}_{2}$ emissions will decrease by $40 \%$ on 1990 . At the same time, the UBA's reference scenario is based on the assumption that Germany's existing plants will continue to operate, in particular the hard coal and lignite-fired installations. However, a significant reduction in greenhouse gases can be achieved by substantially transforming the structure of the energy source mix: the use of coal would be reduced by $30 \%$, the share of natural gas increased from $10 \%$ to $54 \%$, and the share of renewable energy sources raised from $5 \%$ to $21 \%$. The UBA sustainability scenario proceeds on the assumption that there is considerable potential for energy saving and also assumes that a substantial share of electricity will be produced in coal-fired plants. All of the scenarios are based on the assumption that the share of nuclear power used in electricity generation will decrease sharply up to 2020 .

The Enquête Commission on Sustainable Energy Supplies also strongly emphasises improvements in energy efficiency, calculating variations for the structure of the power plant mix. The Commission believes that both the substantial expansion of renewable energy sources and the rehabilitation of nuclear energy are possible. $^{21}$ The Commission also considers the potential of carbon capture and sequestration technology, which would enable the continued use of coal-fired power stations. Economically speaking, while the expansion of gas-fired and steam-driven plants currently seems a reasonable option, their future economic viability will depend crucially on gas price growth. It can therefore be assumed that, like the price of oil, gas prices will remain entrenched at a high level in the long term or even rise further. High gas prices would increase the cost of electricity generation in gas-fired power plants. The creation of a ' $\mathrm{CO}_{2}$-free power plant' via carbon sequestration, i.e. capturing carbon dioxide as it is produced, is also cost

\footnotetext{
18 Bericht der Enquetekommission 'Nachhaltige Energieversorgung unter den Bedingungen der Globalisierung und der Liberalisierung' des 14. Deutschen Bundestages. Bundestags-Drucksache no. 14/9400 of 7 July 2002, pp. 438-455.

${ }^{19}$ Federal Environmental Agency: 'Anforderungen an die zukünftige Energieversorgung - Analyse des Bedarfs zukünftiger Kraftwerkskapazitäten und Strategie für eine nachhaltige Stromnutzung in Deutschland'. Berlin 2003, pp. 11-13; German Council of Environmental Experts: 'Umweltgutachten 2004. Umweltpolitische Handlungsfähigkeit sichern'. Berlin 2004, pp. 9-13.

${ }^{20}$ The scenarios described here are based on the scenarios presented by the Federal Environmental Agency for reducing $\mathrm{CO}_{2}$ emissions by 2020.

${ }^{21}$ Bericht der Enquetekommission 'Nachhaltige Energieversorgung', loc. cit., pp. 345-394.
} 
Figure 3

Expected Power Plant Capacity under Various Scenarios by Share of Energy Source

Gross installed electricity generation capacity in gigawatts

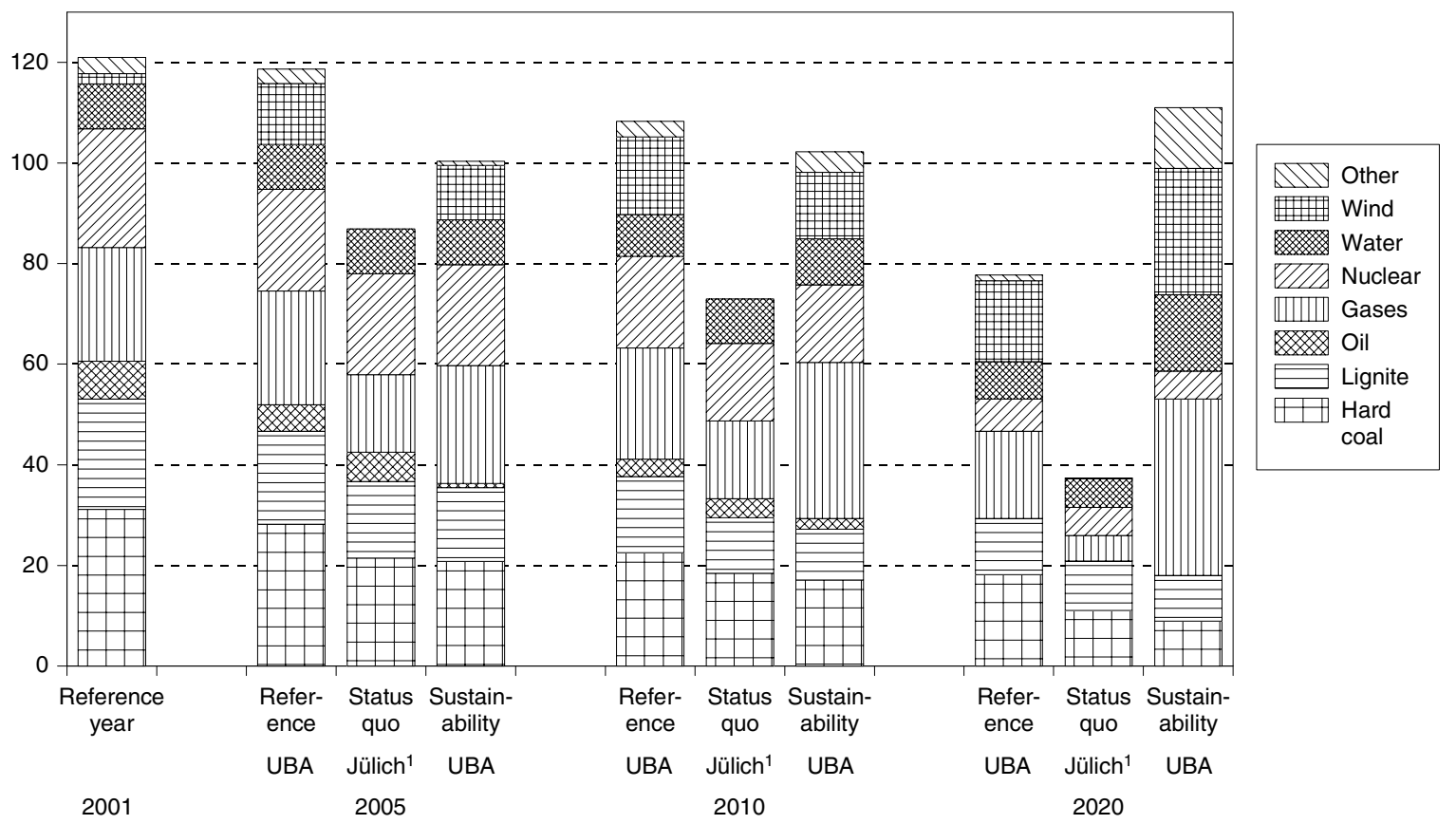

DIW Berlin 2004

1 Jülich Research Centre.

Source: Federal Environmental Agency 2003.

intensive. The cost of carbon capture in a standard power plant is estimated at between 100 and 200 euro per tonne of carbon, ${ }^{22}$ and this in turn would increase the cost of using coal-fired plants. Moreover, the technology of both carbon capture and its final disposal has as yet been inadequately explored. These unknown quantities make it unlikely that this technology can become available as early as 2020. All in all, expenditures on research and development in the energy sector - especially on renewable energy, but also on other environmentally friendly technologies - must be sharply increased. $^{23}$

22 German Advisory Council on Global Change: 'Welt im Wandel: Energiewende zur Nachhaltigkeit'. Berlin 2003, pp. 94-98. More optimistic estimates set the price for carbon capture at between US $\$ 30$ and US \$ 134 per tonne of carbon; cf. R. Williams et al.: 'Advanced Energy Supply Technologies'. In: 'United Nations Development Programme: World Energy Assessment: Energy and the Challenge of Sustainability'. Washington, D.C. 2000, p. 290.

${ }^{23}$ Germany has allocated a much smaller share of research expenditures to the energy sector than other countries, for example the USA and Japan, because spending in Germany has been significantly reduced since the 1990s; cf. Federal Ministry of Economics and Technology: 'Energie-Daten 2003'. Berlin 2003, p. 51.

\section{Emissions trading not a disadvantage for large energy producers}

The future of energy production in Germany and Europe will depend crucially on what emission reduction targets are laid down and become binding in law. The higher the reduction targets, the higher will be the price of emissions permits. In turn, the higher the price of emissions permits, the higher will be the rise in variable costs for emissions-intensive electricity generation technologies. Coal and lignite technologies, in particular, will become relatively expensive and less economically viable (cf. figure 4). However, other studies have shown that at a very high price for emissions permits (over 150 euro per tonne of $\mathrm{CO}_{2}$ ), carbon capture and sequestration technology could become profitable again. ${ }^{24}$

All in all, emissions trading will lead to a rise in electricity prices. Simulations of two scenarios using a game-theoretic model for the European electricity market (EMELIE) ${ }^{25}$ show that under the emissions trading

${ }^{24}$ German Advisory Council on Global Change: 'Welt im Wandel: Energiewende zur Nachhaltigkeit'. Berlin 2003, p. 95. 
Figure 4

Variable Costs of Electricity Generation at Different Emissions Permit Prices ${ }^{1}$

In euro per megawatt hour

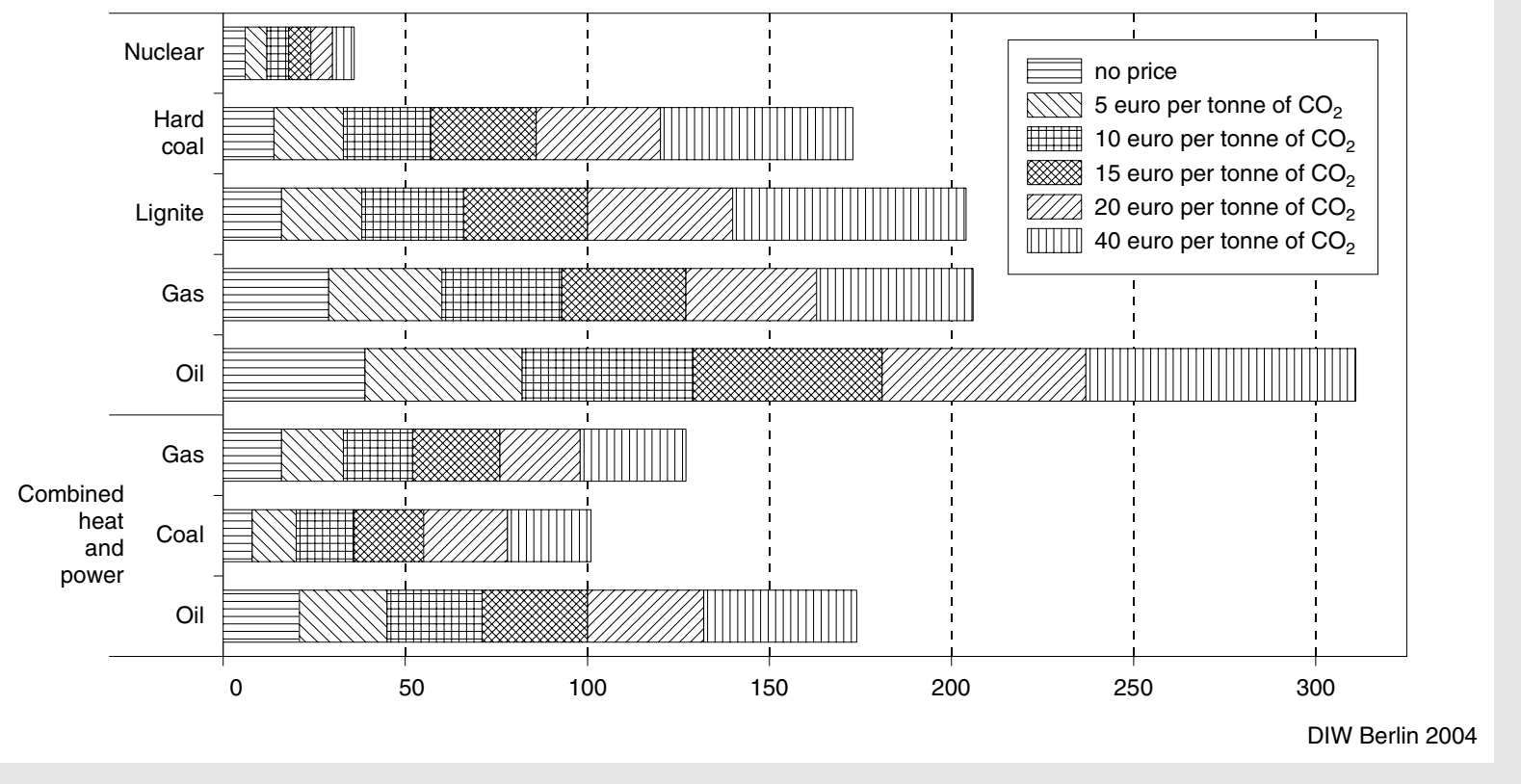

1 Permit prices: 5, 10, 15, 20 and 40 euro per tonne of $\mathrm{CO}_{2}$.

Sources: EMELIE simulation model; DIW Berlin calculations.

system, the electricity price in Germany rises less sharply in fully competitive conditions than in an oligopolistic market situation (cf. figure 5).

\section{Findings using the EMELIE simulation model}

Simulation of emissions trading in Europe shows clearly that only a few energy enterprises will face sharp losses in profits (cf. table 3). Small enterprises, in particular, will be unable to offset the higher cost structure by changing their energy source mix. One of the consequences of emissions trading will be the replacement of emissions-intensive technologies such as coal-fired plants by gas-fired plants and combined heat and power plants (cf. figure 6) ${ }^{26}$ Enterprises with a large portfolio of disposable technologies can react more flexibly and will suffer less severe profit losses. Moreover, a higher electricity price will lead to a rise in firm 'profits'.

As a result, the use of renewable energies might be cheaper in the medium to long term than conventional

${ }^{25}$ Cf. C. Kemfert, W. Lise and R.S.J. Tol: 'Strategic Action in the Liberalised German Electricity Market'. Nota di Lavoro, no. 3, Milan 2003.

${ }^{26}$ The model simulations do not take account of dynamic investment decisions. The status quo assumption is that the new cost burden is met by the technology structure existing in 2000 .
Figure 5

\section{Electricity Price Increases in Germany in Relation to Emissions Permit Price Developments ${ }^{1}$}

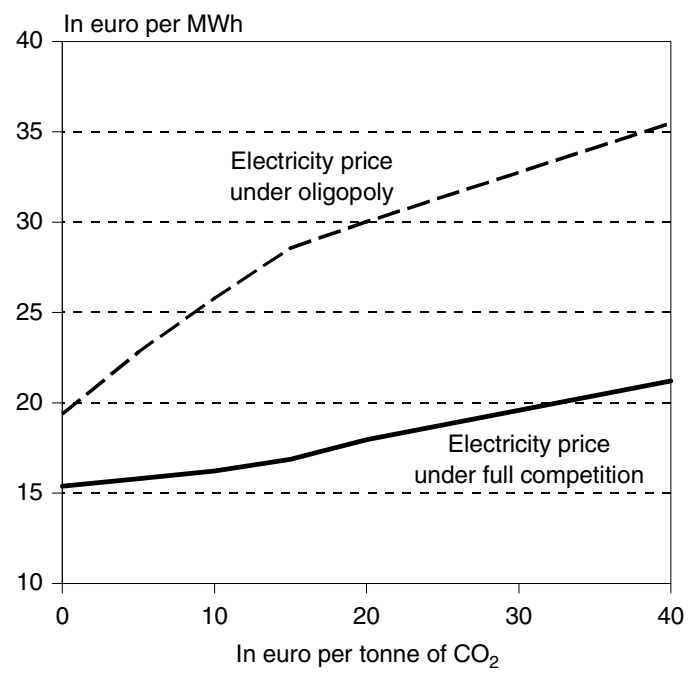

DIW Berlin 2004

1 Electricity price: euro per megawatt hour; emissions permit price: euro per tonne of $\mathrm{CO}_{2}$

Sources: EMELIE simulation model; DIW Berlin calculations. 
Table 3

Change in Corporate Profits at Different Emissions Permit Prices

As $\%$ of reference value

\begin{tabular}{|l|c|c|c|c|}
\hline \multicolumn{1}{|c|}{ European energy suppliers } & $\begin{array}{c}5 \text { euro } \\
\text { per tonne of } \mathrm{CO}_{2}\end{array}$ & $\begin{array}{c}10 \text { euro } \\
\text { per tonne of } \mathrm{CO}_{2}\end{array}$ & $\begin{array}{c}20 \text { euro } \\
\text { per tonne of } \mathrm{CO}_{2}\end{array}$ & $\begin{array}{c}40 \text { euro } \\
\text { per tonne of } \mathrm{CO}_{2}\end{array}$ \\
\hline ElectBEL & 0.13 & 0.24 & 0.54 & 0.94 \\
Elsam & -0.18 & -0.33 & -0.34 & -0.37 \\
E2Energi & -0.17 & -0.41 & -0.47 & -0.57 \\
Fortum & 0.11 & 0.19 & 0.47 & 0.73 \\
PVO & 0.15 & 0.19 & 0.46 & 0.74 \\
EDF & 0.18 & 0.35 & 0.64 & 0.93 \\
EONGER & 0.14 & 0.27 & 0.48 & 0.57 \\
EnBW & -0.07 & -0.07 & 0.01 & 0.02 \\
RWE & 0.04 & 0.13 & 0.32 & 0.45 \\
VattenGER & 0.04 & 0.10 & 0.23 & 0.26 \\
ElectHOL & -0.21 & -0.33 & -0.09 & -0.41 \\
NUON & 0.05 & 0.06 & 0.36 & -0.31 \\
EONHOL & -0.33 & -0.57 & -0.53 & 0.38 \\
Essent & 0.04 & 0.02 & 0.30 & 0.41 \\
Statkraft & 0.13 & 0.20 & 0.39 & 0.68 \\
FrinSWE & 0.19 & 0.36 & 0.62 & 0.69 \\
VattenSWE & 0.19 & 0.36 & 0.62 & 0.75 \\
Sydkraft & 0.20 & 0.39 & 0.66 & 0.62 \\
Birka & 0.18 & 0.33 & 0.56 & \\
\hline
\end{tabular}

Sources: EMELIE simulation model; DIW Berlin calculations.

Figure 6

Change in Electricity-generating Technologies at Different Emissions Permit Prices

As $\%$ of reference value
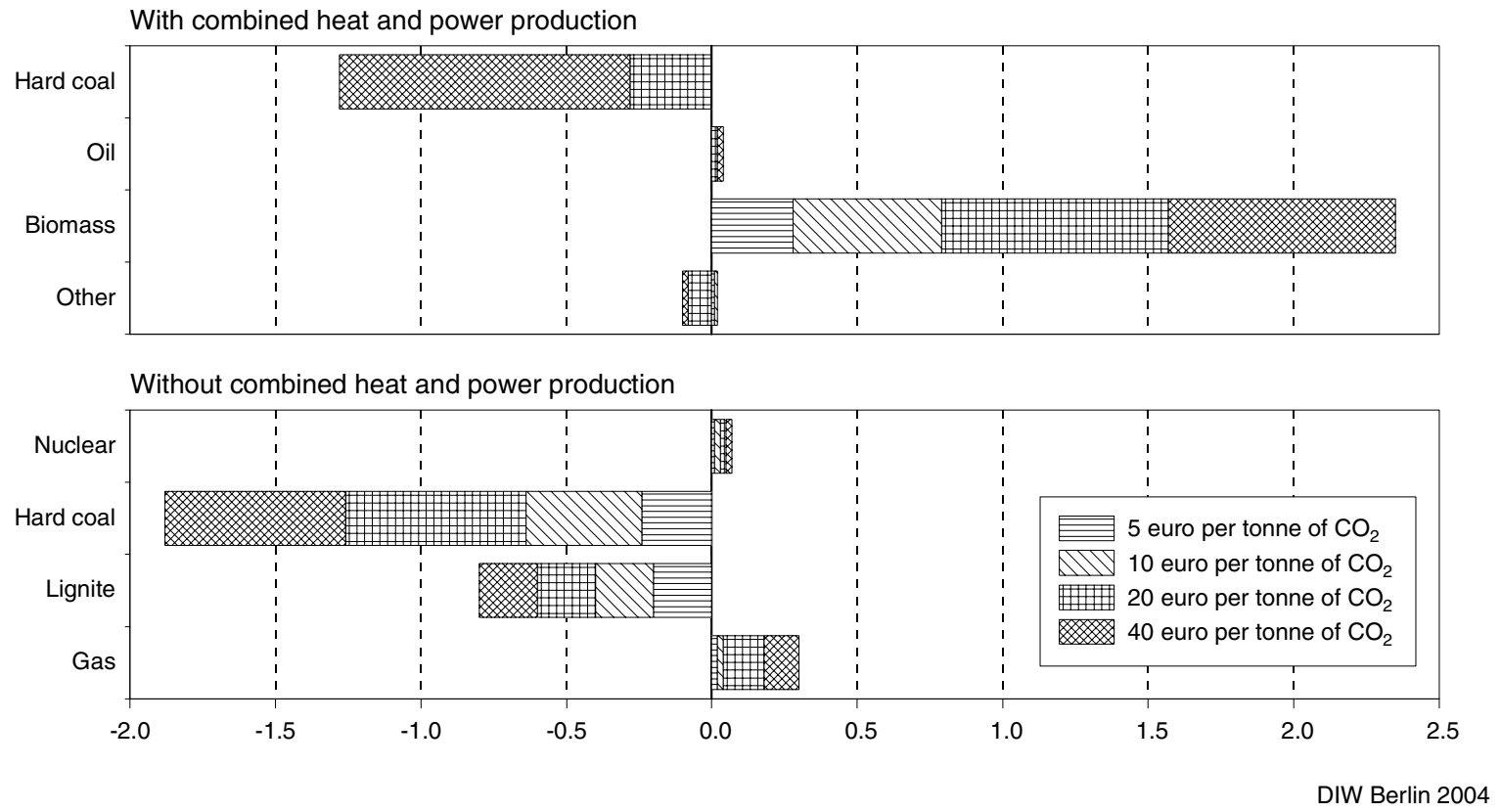

Sources: EMELIE simulation model; DIW Berlin calculations. 
energy technology. However, it must be assumed that in the long term the actual costs of conventional production technologies will become aligned again with those based on renewable energy sources. The higher the rise in oil and gas prices and in the cost of reducing emissions (via purchase of emissions permits or the costs of carbon capture), the sooner renewable energy technologies will become competitive. At the same time, the progressive liberalisation of the European electricity market will exert substantial pressure on the cost of electricity generation. As a result, efforts to uphold or even accelerate climate protection and energy policy in Europe will mean that environmentally friendly technologies can obtain a competitive advantage.

\section{Conclusion}

The power plants of the future will be both increasingly cost efficient and increasingly gentle on environment and climate. The greatest competitive advantages can be expected in the area of environmentally friendly technologies. However, these advantages can only be secured if electricity production is soon restructured. Waiting for the medium or long term to begin the transformation will generate much higher costs for the German economy. Given that Germany's power plants require modernisation anyway, German energy producers now have a unique opportunity not only to satisfy the demands of future climate protection policy, but also to secure global market leadership in this domain.

Claudia Kemfert 